Çukurova Üniversitesi Mühendislik Mimarlık Fakültesi Dergisi, 31(2), ss. 355-363, Aralık 2016

\title{
Gazimağusa Kaleiçindeki Tarihi Taş Yapılarda Görülen Bozunmalar
}

\author{
Murat DAL $^{* 1}$, Mahmut YALÇIN ${ }^{1}$, Ali Duran ÖCAL ${ }^{2}$ \\ ${ }^{1}$ Munzur Üniversitesi, Mühendislik Fakültesi, İnşaat Mühendisliği Bölümü, Tunceli \\ ${ }^{2}$ Universidad Nacional de Colombia, Fakultad de Ciencias Humanas, Departamento de \\ Antropologia, Bogota (Kolombiya)
}

Geliş tarihi: 13.06.2016 Kabul tarihi: 23.11.2016

Öz

Bu çalışmada Kıbrıs’taki Gazimağusa liman kentinde Kaleiçi bölgesindeki tarihi eserlerin karşılaştığı sorunlar ele alınmıştır. Bu bölgedeki tüm anıt ve yapıların bozunmaya uğramış olması endişe vericidir. Yapı taşlarında gözlenen ayrışma formları, birbirleriyle etkileşen bozunma faktörlerinin neden olduğu ve geliştirdiğini bozunma sürecinin sonuçlarını örneklemektedir. Kaleiçi'ndeki antik binalar ve anıtlarda gözlenen ayrışma formları ve ayrışma ürünleri, taşlardaki bozunmanın, Akdeniz'den gelen tuzların nemle etkileşimi sonucu oluştuğunu göstermektedir. Bu çalışmada, Gazimağusa'nın bu tarihi bölgesinde gözlenen tahribatın ilk sonuçları sunularak eski eserlerin koruma önlemlerinin gerekliliği ve aciliyeti vurgulanmak istenmiştir.

Anahtar Kelimeler: Tarihi eser, Bozunma, Tahribat, Doğal yapı taşı

\section{Deterioration of the Historic Stone Building of the City Gazimagusa Kaleiçi}

\begin{abstract}
In this study the problems faced by the historical monuments in Old City port town of Famagusta in Cyprus are discussed. All monuments and buildings of this area have suffered weathering damage and the destruction is worrying. Weathering forms exemplify the observable consequences of weathering progressions which are originated and controlled by interacting weathering elements. For these ancient buildings and monuments in the Kaleiçi the valuation of weathering forms and weathering products indicates the correlations between the development of weathering damage and salt from Mediterranean Sea loading to the stones as a consequence of humidity. The first results of weathering damage on these historic area in Gazimagusa are presented and they exhibit the need and urgency of monuments preservation measures.
\end{abstract}

Keywords: Historic buildings, Deterioration, Destruction, Natural building stone

\footnotetext{
*Sorumlu yazar (Corresponding author): Murat DAL, teknikmurathoca@gmail.com
} 


\section{GíRiş}

Gazimağusa, Kıbrıs'ın doğusunda, kuzeyde Karpaz Yarımadası ile güneyde Poyraz Burnu arasında, kuzey ve güney rüzgarlarına kapalı Gazimağusa Körfezinin daha yakın bir noktasında konumlanmıştır [1]. Geçmişten gelen, günümüze ve geleceğimize 1şık tutan çok değerli olan fakat birçok kişinin farkında olmadığı tarihi eserlerimiz maalesef birçok sebepten dolayı görünümünü, yapısını ve etkisini göz göre göre kaybetmektedir [2].

Peki bizim için çok önemli olan bu tarihi eserler neden bozunmaya uğramaktadır? Tarihi eserlerde meydana gelen bozunmaları önlemek, sadece bu tür bozunmaları engellemek için kurulan kuruluşlardan beklenmemelidir. Her fert bu önemli konuda üzerine düşen yükümlülüğü yerine getirmelidir. Aksi taktirde geleceği geçmişi görmeyerek kuramayız buda tecrübe olmadan yaşamak demektir. Yeni doğan bir bebeğin aniden çok daha ileriki yaşlarda yaşaması demektir, aynı zamanda geçmiş olmadan geleceğe yürümek demektir.

Bu çalışmada Kuzey Kıbrıs Türk Cumhuriyeti sınırları içerisindeki Gazimağusa liman kentinde Kaleiçi bölgesindeki (Şekil 1) tarihi eserlerin karşılaştığı sorunlar ele alınmıştır. Bölgede bulunan tarihi eserler yerli ve yabanci turistler tarafından çok ilgi görmektedir. Fakat kayıp giden mirasın önüne geçilememekte ve bu konuda bir farkındalık yaratılamamaktadır.

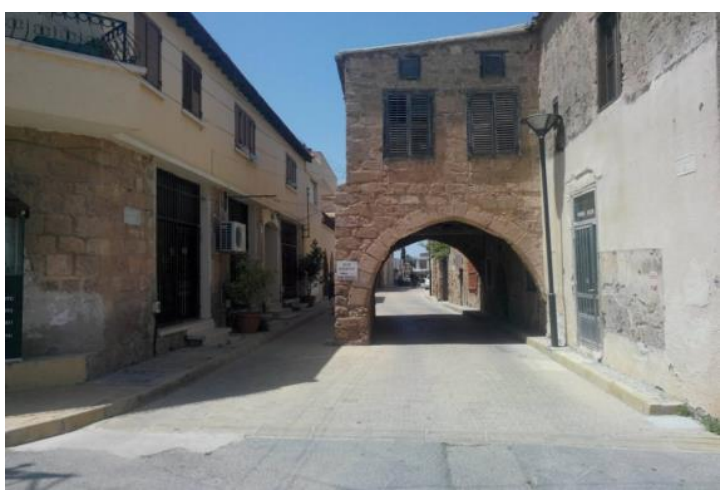

Şekil 1. Gazimağusa Kaleiçi çarşı merkezden genel bir görünüm

\section{MATERYAL VE METOT}

Araştırmada, ana materyal olarak, Kuzey Kıbrıs Türk Cumhuriyeti sınırları içerisindeki Gazimağusa liman kentindeki tarihi taş eserlerdeki bozunmalar ele alınmıştır. Gazimağusa Kaleiçi yapılarında gözlemler yapılmış, farklı bozunmalara yönelik örnekler verilmiş, çeşitli yöntemler kullanılarak belgelenmiş [3] ve değerlendirilmiştir. $\mathrm{Bu}$ yapı taşlarındaki bozunmalar tespit edilerek literatür bilgileri ile karşılaştırılmıştır [4-14]. Bu araştırmada, gözlem analiz sentez yöntemi [3] kullanılmış, taş bozunmalarına dikkat çekilmeye çalışılmıştır.

\section{TARIHII TAŞ YAPILARDAKİ BOZUNMALAR}

Yapı taşlarının bulunduğu çevrenin iklimsel özellikleri onların bozunmasında önemli bir rol oynamaktadır. Bunun yanında, bozunma türünün, kayacın fiziksel ve kimyasal yapısı ile dış ve iç etkilerin özelliklerine bağlı olduğu bilinmektedir. Taş yapıların yıpranması ve bozunmasındaki süreci hazırlayan etmenler, genellikle bir çoğu birlikte etkili olan fiziksel, kimyasal ve biyolojik nedenlerdir (Şekil 2).

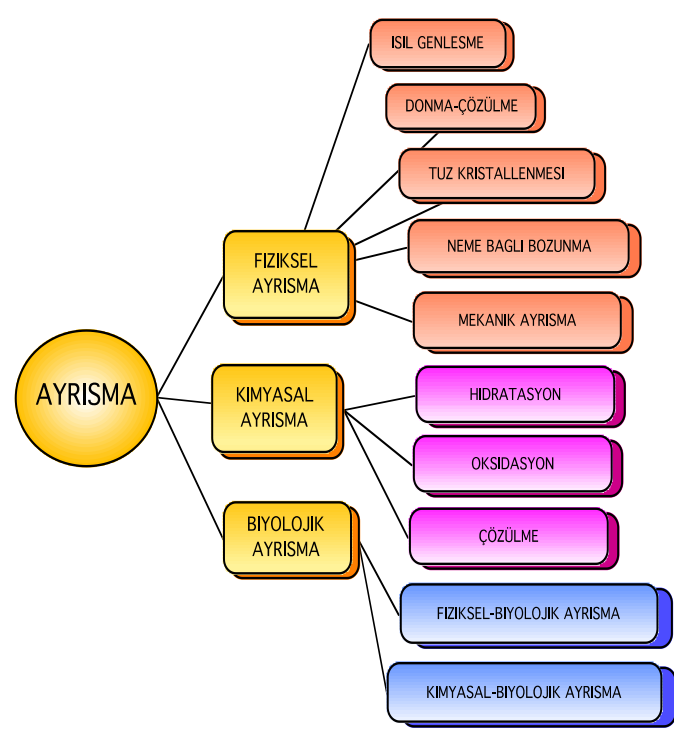

Şekil 2. Taşların bozunmasına neden olan ayrışmaların genel bir sınıflandırması [2] 
Sicaklığın, nemin ve tuz oranının fazla olduğu Gazimağusa liman kentinde de yeterli tedbirlerin alınamadığı ve kaybın önüne geçilemediği görülmektedir. Kaleiçi'ndeki tarihi eserlerde gözlenen tahribatları genel olarak fiziksel bozunmalar (çatlaklar, kırıklar, petek gözlülük ve parça kaybı), kimyasal bozulmalar (siyah tabakalar, tuzlanmalar, tozlaşmalar) ve biyolojik bozulmalar (köklü ve yapraklı bitkiler) olarak sınıflandırmak mümkündür. Ayrıca biyolojik bozulmalar hem kimyasal hem de fiziksel ayrışmaya neden olduğundan bazı durumlarda bu iki bozulma grubu içinde de incelenebilir.

\subsection{Fiziksel Bozunmalar}

Tarihi eserlerde fiziksel bozunma deyince akla ilk olarak dış etkenlerden kaynaklanan kuvvet sonucu yapısının değişmesi akla gelir. Başka bir deyişle taşlardaki fiziksel ayrışma, taşları oluşturan minerallerin yapılarında bir değişme oluşmadan, bağlarının zayıflanarak parçalara ayrılıp ufalanmasıdır.

Özellikle Gazimagusa kentinin bulunduğu yerdeki yüksek sıcaklık farkı, tuz, buz ve kök çatlatmasıyla kayaları oluşturan minerallerin bağlarının gevşemesi sonucu taşların fiziksel (mekanik) olarak parçalanması sıkça gözlenen bir olaydır. Mekanik çözünmede taşların fiziksel yapıları etkili olmakla birlikte, iklim koşulları daha fazla etkilidir. Zira sıcaklık farkının artması, mekanik çözünmeyi artırır.

Tarihi eserleri fiziksel olarak etkileyen faktörler, bir eserin uygun yerleştirilememesi, amacından farklı bir biçimde kullanılması ve günümüzde de tarihi eser değil de daha çok işe yarar yapılar olarak görülmesi gibi etkenlerde eserin bozunmasına neden olabilir.

Çatlaklar: Tarihi eserlerde; bütün olan parçada, doğrusal veya doğrusal olmayan belli bir doğrultuda oluşan boşluklu kıvrımlardır. Eserlerde oluşan çatlaklar; birleştirici maddenin yapısını kaybetmesi, dış etkenlerden dolayı, eserin yapısında kullanılan taşın cinsi, yağan asidik yağmurlar, sıcaklık, nem vb. nedenlerden dolayı oluşmaktadır (Şekil 3, Şekil 4). Kılcal ve yapısal olarak tanımlanan çatlaklar Gazimağusa Kaleiçi'ndeki birçok heykel ve yapılarda gözlenmektedir.

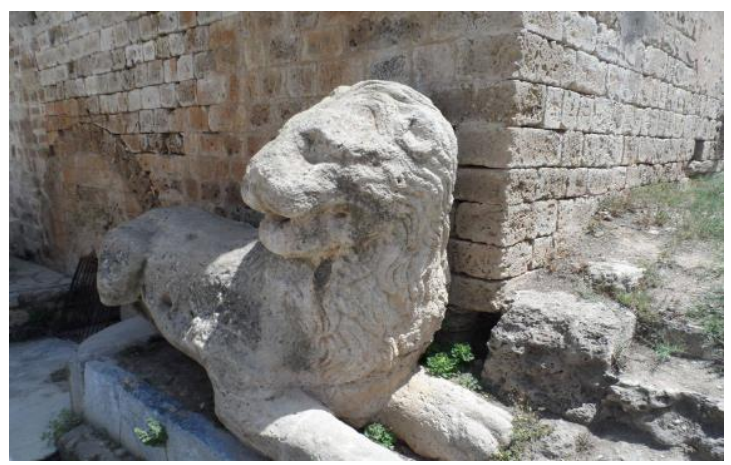

Şekil 3. Gazimağusa Kaleiçi Çarşı Merkezdeki aslan heykelindeki büyük parça kayıpları

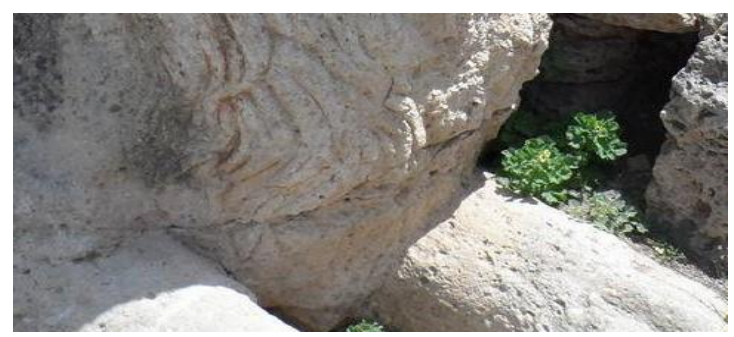

Şekil 4. Gazimağusa Kaleiçi Çarşı Merkez aslan heykeli alt boyun kesimindeki çatlak

Kırıklar: Olumsuz dış etkilerden dolayı, uygulanan kuvvetten dolayı ve taşların minerallerini kaybetmesi sonucu parçaların tamamen birbirinden ayrılmasıdır. Bu bölgede insanların da fazla tahrip etmesi sonucu çok fazla kırıklar meydana gelmiştir (Şekil 5).

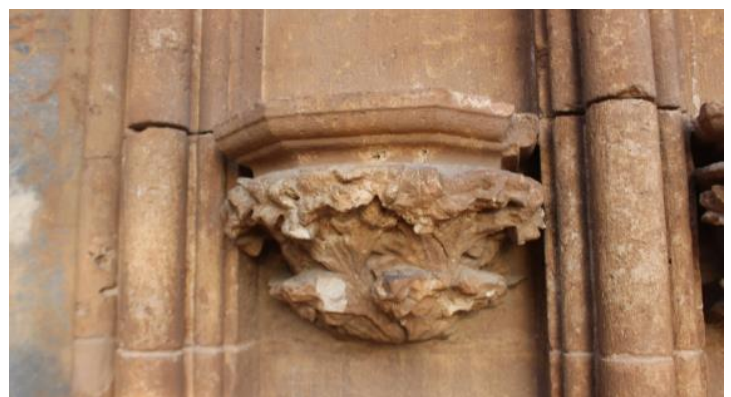

Şekil 5. Gazimağusa Kaleiçi Lala Mustafa Paşa Camiisi giriş cephesinde görülen kırılmalar 
Petek Gözlülük: Tarihi eserlerin yüzeylerinde birbirine bağlanan birbirinden bağımsız çukurların meydana gelmesidir. Genelde taşların yüzeyleri süngerimsi bir yapıya sahip olur ve özellikle fosil içeren taneli yapıdaki taşlarda gözlenen bir bozunma türüdür. Alveolar ayrışma veya oyuklanma olarak ta tanimlanabilen petek gözlülüğün oluşmasının sebebi atmosferden gelen farklı kimyasal maddeler örneğin asidik yağmurlar, denize yakın yerlerde nem ve tuz oranının fazlalığından da meydana gelir (Şekil 6-8). Ayrıca yüzeyde oluşan bu oyuklar nedeniyle taştaki bozunmaya eğilimli olan bölge arttığından taşın yıpranması daha da hizlanır.

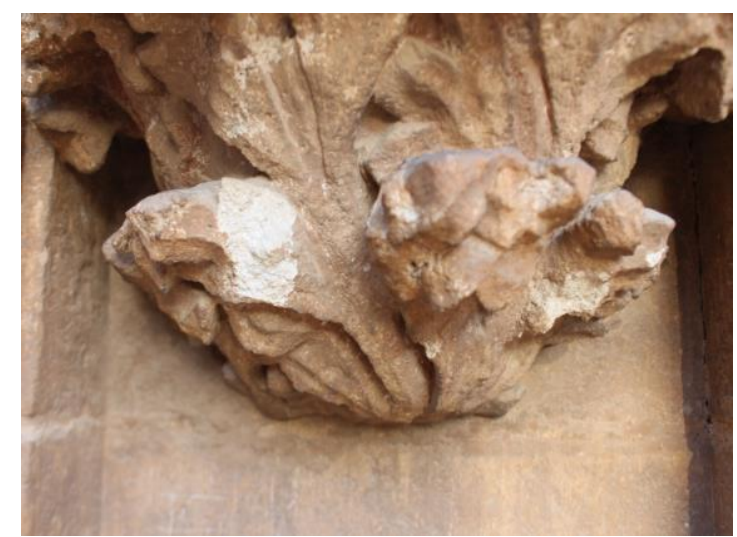

Şekil 6. Gazimağusa Kaleiçi Lala Mustafa Paşa Camiisi giriş cephesinde görülen çukurlaşmalar

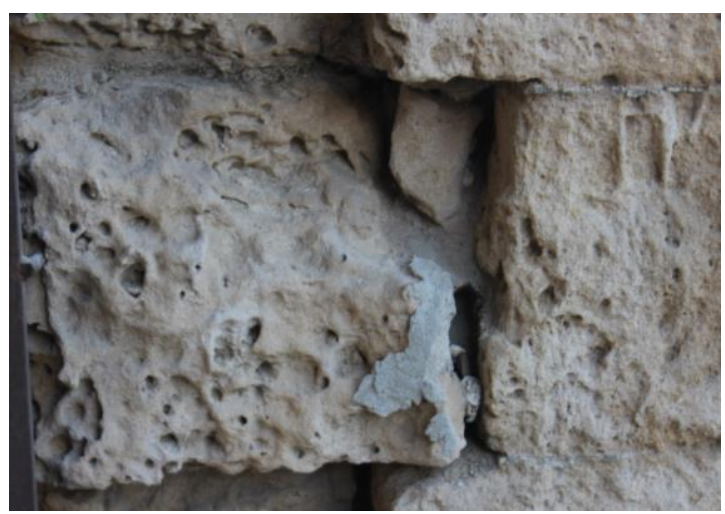

Şekil 7. Gazimağusa Kaleiçi St. Nikolas Katedrali giriş cephesinin iç kısmının yapı taşlarında görülen oyuklanmalar

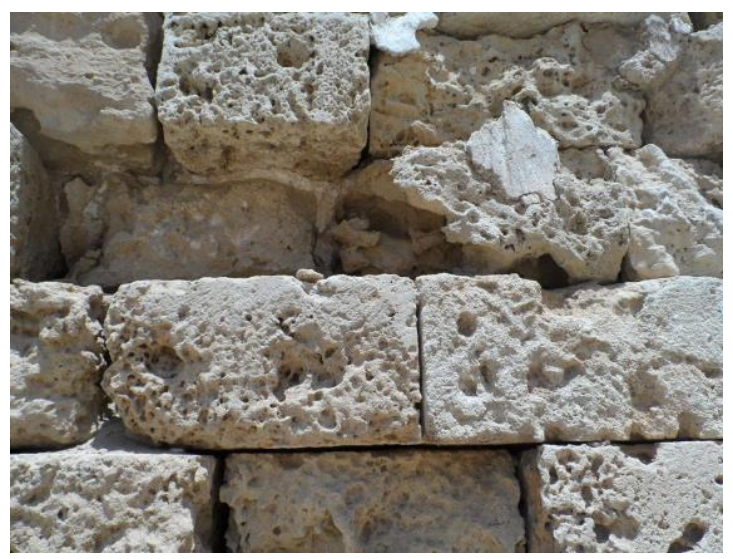

Şekil 8. Gazimağusa Kaleiçi St. Nikolas Katedrali giriş cephesinin iç kısmının yapı taşlarında görülen parça kayıpları, yüzeysel erimeler ve çukurlaşmalar

Parça Kaybı: Özellikle heykel gibi tarihsel ve sanatsal değeri olan tarihi eserlerin; parmak, kol, burun gibi detayların farklı kuvvetlerin etkisiyle eserlerden ayrılmasıdır (Şekil 9-11). Eserlerdeki parça kaybı yüzeyin zaman içerisinde aşınarak erozyona uğraması veya dış bir etkenden dolayı kırılması şeklinde gerçekleşebilir.

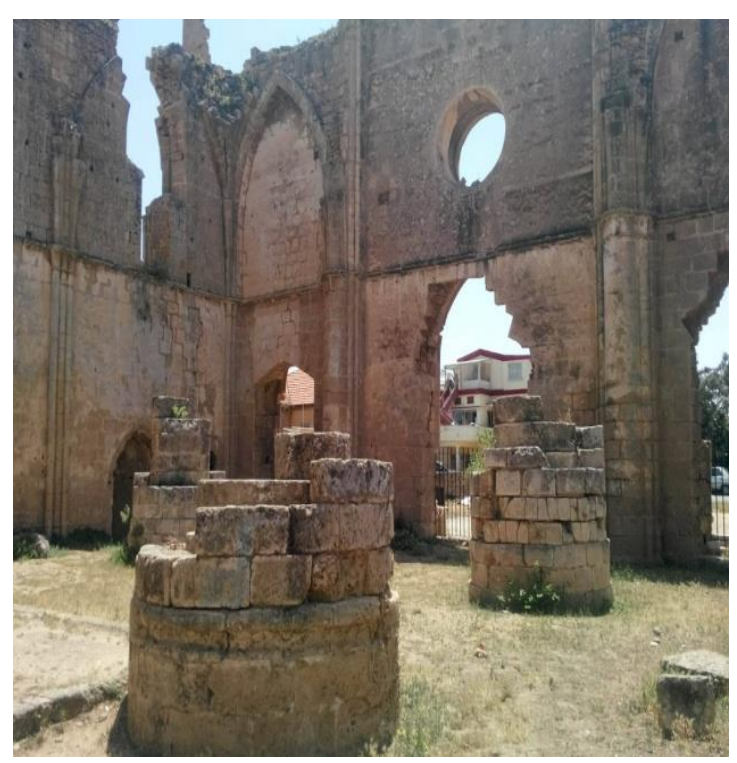

Şekil 9. Gazimağusa Kaleiçi St. Nikolas Katedralindeki yapı taşlarında görülen büyük parça kayıpları 


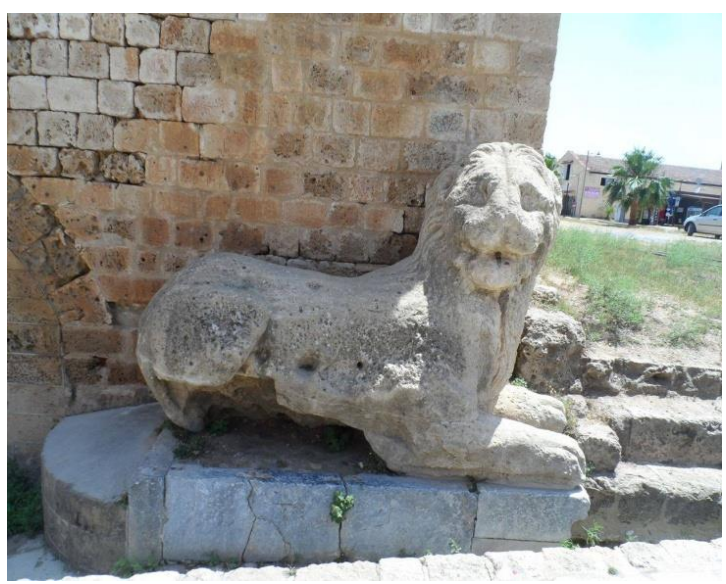

Şekil 10. Gazimağusa Kaleiçi St. Nikolas Katedrali girişindeki oturmuş durumdaki aslan heykelinin arka bacaklarında görülen büyük parça kayıpları

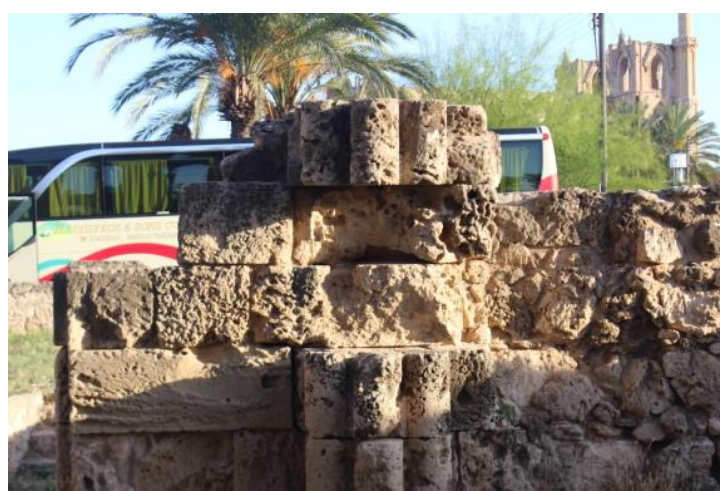

Şekil 11. Gazimağusa Kaleiçi St. Nikolas Katedralindeki yapı taşlarında görülen erime ile oluşmuş büyük parça kayıpları

\subsection{Kimyasal Bozunmalar}

Taşın kimyasal bileşiminde oluşan değişim sonucunda yapı taşını oluşturan minerallerin başka minerallere dönüşmesi olayı "kimyasal çözünme" olarak nitelendirilir ve karbondioksit, su, oksijen ve mikroorganizmaların etkisiyle hep birlikte hareket etmesi ile gelişir. Kimyasal bozunmadaki temel etkenler nem oranı ve sicaklıktır.

Eserlerin oluşturulduğu taşların yapısının değişmesi sonucu yapı taşlarında meydana gelen renk değişimi, tuzlaşma, gölgelenme gibi tahribatların oluşması sözkonusudur.
Siyah Tabakalar: Bu tür bozunmalar direk olarak yağmura maruz kalan taş eserlerde meydana gelir. $\mathrm{Bu}$ bölgede de nem oranının fazla olmasından dolayı meydana gelen siyah tabakalar oldukça fazladır (Şekil 12-13).

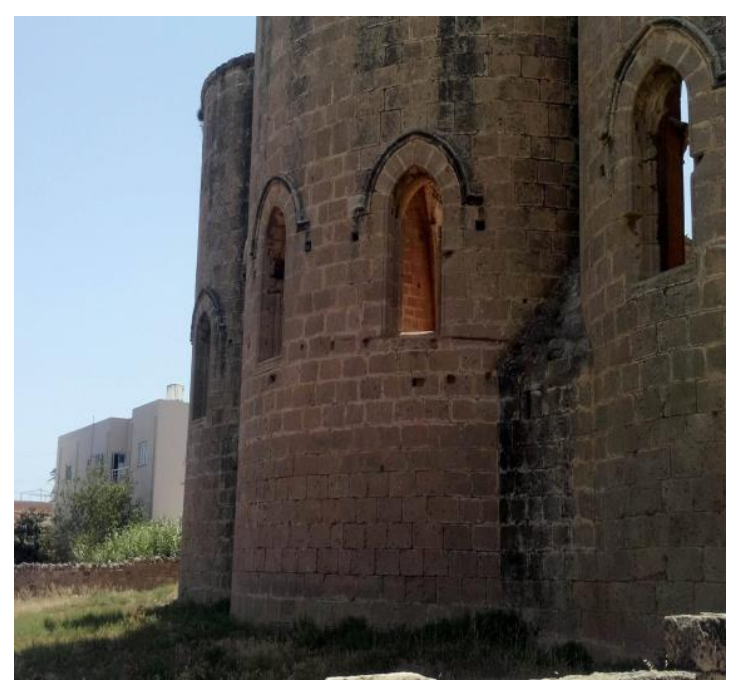

Şekil 12. Gazimağusa Kaleiçi Lala Mustafa Paşa Camiisi güney cephesinde yap1 taşlarında görülen siyah lekelenmeler

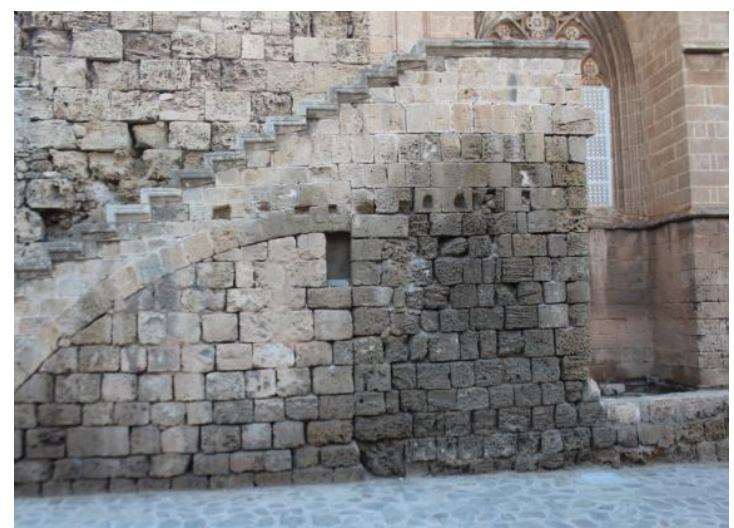

Şekil 13. Gazimağusa Kaleiçi Lala Mustafa Paşa Camiisi güney cephesindeki yap1 taşlarında su-nem etkisi ile oluşmuş renk farklılıkları

Tuzlanmalar: Taş eserlerin yapısında bulunan tuz mineralleri, nem veya yağmur etkisiyle çözünürler. Bu bölgede sicaklık derecesi yüksek olduğundan hemen buharlaşıp kristalleşirler (Şekil 14-16). 


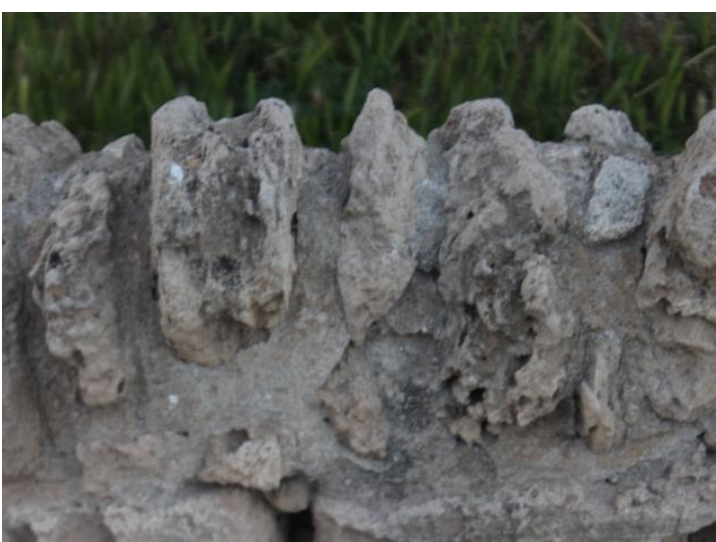

Şekil 14. Gazimağusa Kaleiçi kale surları ön cephesindeki yapı taşlarında tuz etkisi ile oluşmuş yüzeysel erozyonlar

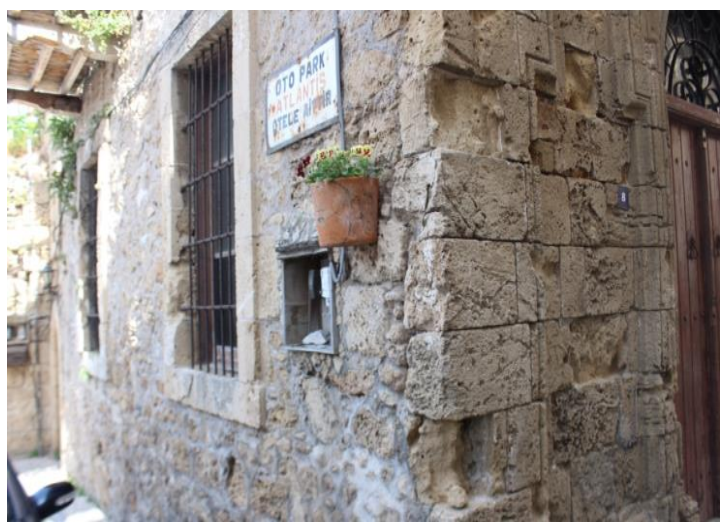

Şekil 15. Gazimağusa Kaleiçi kale surları ön cephede tuzların oluşturduğu erozyon

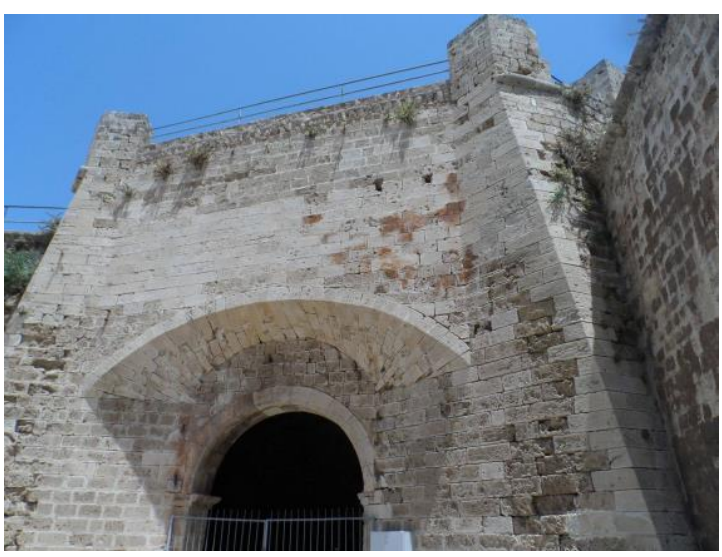

Sekil 16. Gazimağusa Kaleiçi kale surları ön cephesindeki yapı taşlarında tuz etkisi ile oluşmuş aşınmalar

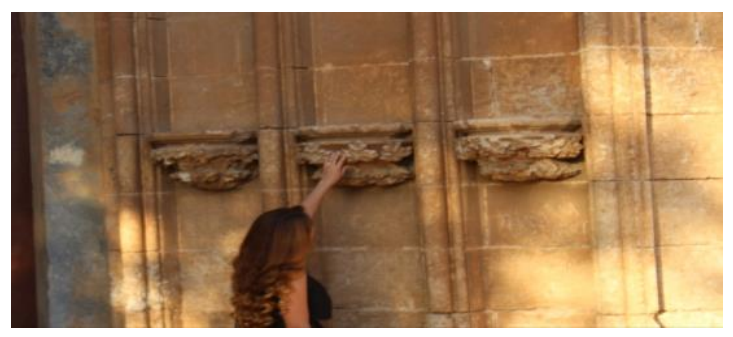

Şekil 17. Gazimağusa Kaleiçi Lala Mustafa Paşa Camiisi giriş cephesi yapı taşlarına sık sık insan eli dokunmalarından dolay 1 oluşan parlaklık

Tozlaşmalar: Tozlaşmalar granüllü taşlarda görülür. Taşı yüzeyindeki granüller bağlayıcılarını kaybederek toz halinde yüzeyden ayrılır. Yüzeye dokunma, iklim şartları gibi nedenlerle eserlerin yüzeylerinde tozlaşma meydana gelir (Şekil 17, Şekil 18, Şekil 19).

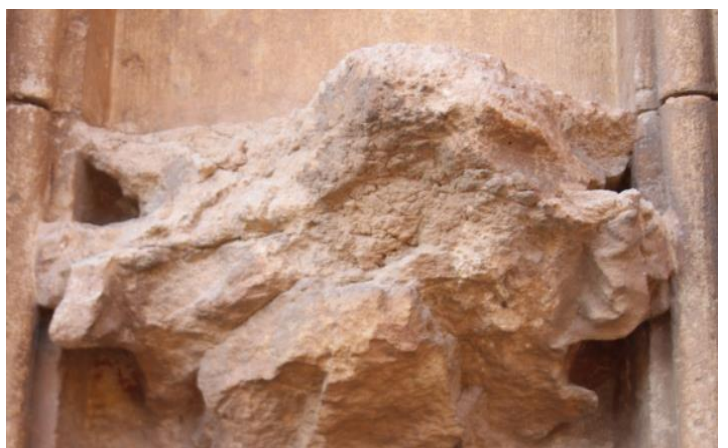

Şekil 18. Gazimağusa Kaleiçi Lala Mustafa Paşa Camiisi giriş cephesindeki yap1 taşlarında görülen tozlanmalar

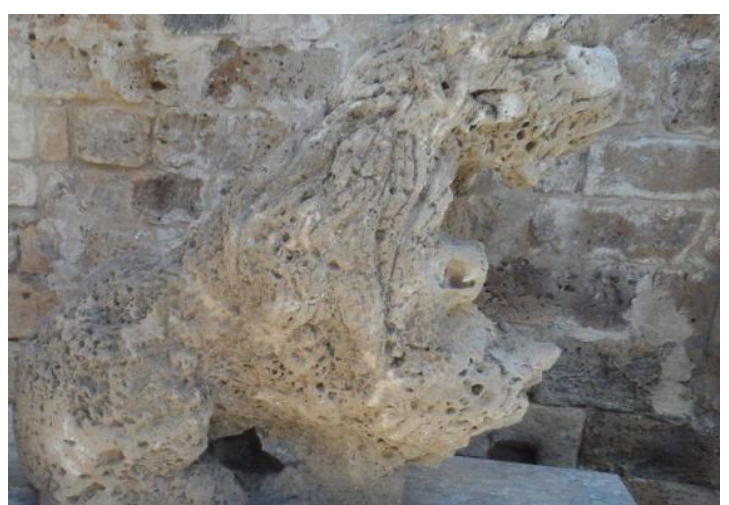

Şekil 19. Gazimağusa Kaleiçi Lala Mustafa Paşa Camiisi giriş cephesi yapı taşları 


\subsection{Biyolojik Bozunmalar}

Taş yapıların ve eserlerin bozunmasına neden olan etmenlerden birisi de canlılardır. Değiş̧ik türden hayvanlar ve böcekler, kazıma ve tırmanma gibi mekanik olgularla veya çıardıkları asitler dolayısıyla kimyasal ayrışmaya neden olmakla birlikte fiziksel ayrışmaya da neden olabilirler. Oyucu hayvanlar ise kayaçları oymakla hem kayacın dayanıklılı̆ıını azaltır hem de kimyasal ayrışmayı hızlandırır. Bitki kökleri veya gövdeleri büyüme sırasında yapı taşlarını da kolayca parçalayabilir.

Kuşlar, tırmanıcılar, solucan gibi büyük hayvanlar da taşlarda delikler ve oyuklar meydana getirebilmelerinin yanında, organik madde ve atmosferden nitrojen tutan bakteriler de ayrışmıș, taş yüzeylerinde ve çatlaklarında yı̆̆ı̆şarak taşların daha hızlı bozunmasına neden olabilirler.

Gazimagusa Kaleiçi'ndeki tarihi eserlerde meydana gelen biyolojik bozunmalar da yukarıda sözü edilen etmenlerden dolayı gerçekleştiği gözlenmektedir. Aynı şekilde buradaki taş eserlerin yapısındaki mineralerin çözünmesine, duvarlardaki derz aralarına yerleşen canlıların veya bitkilerin neden olduğu anlaşılmaktadır.

Köklü ve Yapraklı Bitkiler: Rüzgarlar yardımıyla taşınarak derzlere ve taş yüzeyindeki mikroboşluklara yerleşen tohumların, zaman içinde büyüyerek bitki haline gelmesi çok yaygın bir döngüdür. Buralarda gelişerek zamanla ağaca dönüşen bu bitkilerin kökleri ve düșen yaprakları eserlere oldukça fazla zarar verir. Aynı zararı otsu bitkiler de verirler fakat ağaçlar kadar tahrip etmezler (Şekil 20-22).

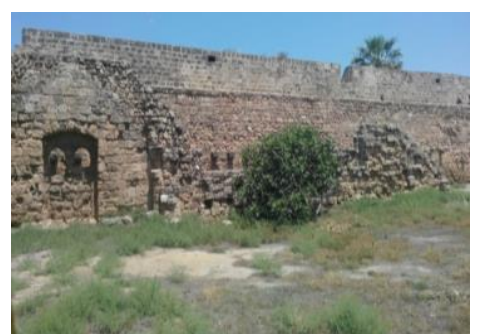

Şekil 20. Gazimağusa Kaleiçi duvarındaki yüksek bitki tahribatı

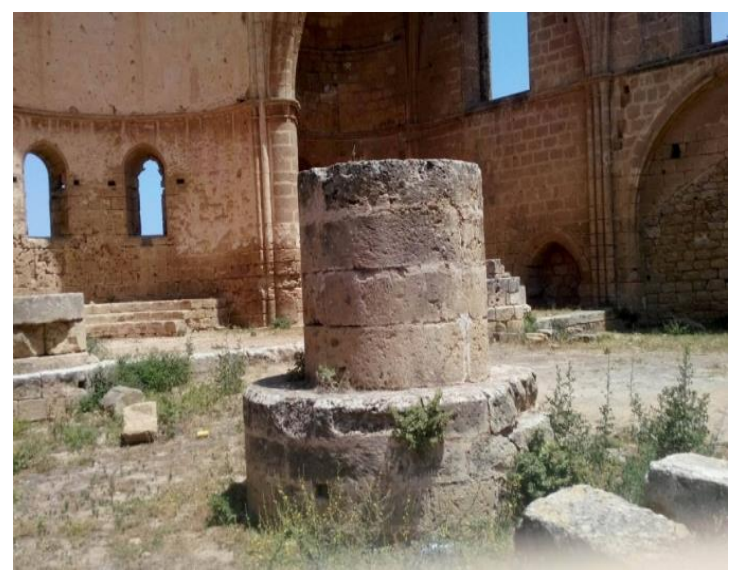

Şekil 21. Gazimağusa Kaleiçi yapı taşları üzerindeki otsu bitkilerin oluşturduğu hasarlar

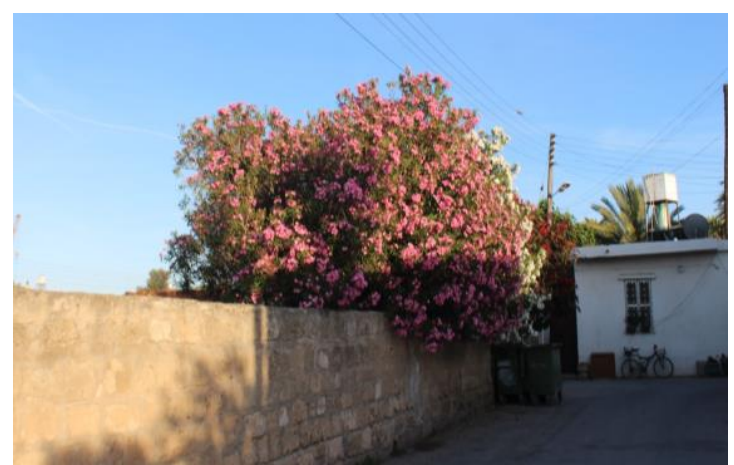

Şekil 22. Gazimağusa Kaleiçi duvarlarındaki yüksek bitki damarları zamanla taş duvarı hasara uğratacaktır

\section{SONUÇLAR}

Taş yapılarda oluşan bozunmanın veya ayrışmanın hızı ve niteliği iklime ve zamana bağlıdır. Yukarıda sözü edilen etkenler az veya çok oranda katk1 sağlamakla birlikte, iklim süreçleri ayrışmanın niteliğini doğrudan etkileyen en önemli öğedir.

Fiziksel, kimyasal ve biyolojik bozunmalar birbirleriyle etkileşerek gelişirler. Fiziksel ayrışma taşları küçük parçalara ayırarak yüzey alanını arttırırken kimyasal ayrışmayı hızlandırır. Kimyasal bozunma da ana minerallerini güçsüzleştirerek fiziksel ayrışmaya yardımcı 
olurken biyolojik etmenler de kök uzatarak parçalama, bakteri ve asidik solüsyon üreterek çözme gibi olgularla yapı taşlarının ayrışmasını hizlandirırlar.

Sonuç olarak bölgedeki tarihi taş eserlerde meydana gelen bozunmaların en genel nedenleri; sıcaklık ve nemden dolayı taşların yapısının değişmesi, ada olmasından ötürü ve denizdeki tuz oranının fazla olmasından dolayı tuzlaşma ve tarihi eserlere insanların dikkatsiz, bilinçsiz yaklaşımı eserlere zarar vermektedir.

$\mathrm{Bu}$ konu hakkında insanlar daha çok bilinçlendirilmeli ve eserlerin restorasyonları zamanında bilirkişiler tarafından periyodik olarak yapilmalidir.

Uluslararası platformda, anıt-eserlerdeki bozunmaların onarılması için, ayrışmalara neden olan kaynakların gözlenerek belirlenmesi, çalışmaların ilk aşamasını oluşturur. Yerinde yapılacak ilk bozunma türü saptamaları yine uluslararası kabul edilen genel terminoloji yardımıyla belgelenerek ortaya konulmalı ve bu bilgiler daha sonrasındaki tarihi eserle ilgili gerekli koruma yöntemlerini belirlemede kullanılmalıdır.

\section{KAYNAKLAR}

1. Uluca, E., 2006. Gazimağusa Kaleiçi’nin Tarihsel Süreç İçindeki Kentsel Gelişimi ve Değişimi, İTÜ Fen Bilimleri Enstitüsü Doktora Tezi, İstanbul.

2. Öcal, A.D., Dal, M., 2012. Doğal Taşlardaki Bozunmalar, Mimarlık Vakfı İktisadi İşletmesi, İstanbul.

3. Fitzner, B., 2004. Documentation and Evaluation of Stone Damage on Monuments.In Kwiatkowski, D. \& Löfvendahl, R. (ed.): Proceedings of the $10^{\text {th }}$ International Congress on Deterioration and Conservation of Stone, 27 June-2 July 2004, Stockholm, Vol. II, 677-690, ICOMOS, Sweden.

4. Fitzner, B., Heinrichs, K., 2004. Photo Atlas of Weathering Forms on Stone Monuments.www.stone.rwth-aachen.de, Internet homepage der Arbeitsgruppe, Natursteine und
Verwitterung des Geologischen Instituts der RWTH Aachen.

5. Fitzner, B., Heinrichs, K., Kownatzki, R., 1995. Weathering Forms-classification and Mapping. In: SNETHLAGE, R. (ed.) Denkmalpflege und Naturwissenschaft, Natursteinkonservierung I. Ernst and Sohn, Berlin, 41-88.

6. Fitzner, B., Kownatzki, R., 1991. Klassifizierung der Verwitterungsformen und Kartierung von Natursteinbauwerken. Jahresberichte aus dem BMFTForschungsprogramm SteinzerfallSteinkonservierung, 1, 1-13.

7. Heinrichs, K., 2004. Weathering Progression on Rock-cut Monuments in Petra / Jordan.-In Akasheh, T.S. (ed.): First International Conference on Science and Technology in Archaeology and Conservation, 12-17 August 2002, Jordan, 207-279, Actas, Fundación El Legado Andalusi, Granada / Spain.

8. Kownatzki, R., 1997. Verwitterungszustandserfassung von Natursteinbauten unter Besonderer Berücksichtigung Phänomenologischer Verfahren. Aachener Geowissenschaftliche Beiträge, 22.

9. Siegesmund, S., Auras, M., Snethlage, R. (eds.), 2005. Stein. Zerfall und Konservierung. Edition Leipzig, Leipzig.

10. Vergès-Belmin, V., Anson Cartwright, T., Cassar, J., Charola, E., De Witte, E., DelgadoRodriguez, J., Fassina, V., Fitzner, B., Fortier, L., Franzen, C., Garcia de Miguel, J.-M., Klingspor-Rotstein, M., Krumbein, W.E., Lefèvre, R.-A., Maxwell, I., Nishiura, T., Queisser, A., Pallot-Frossard, I., Snethlage, R., Tourneur, F., Vallet, J.-M., Van Hees, R., Varti-Matarangas, M., Warscheid, T., Winterhalter, K., 2004. An Internet-Accessible Multilingual Illustrated Glossary on Stone Deterioration.-Proceedings of the $10^{\text {th }}$ International Congress on Deterioration and Conservation of Stone, 27 June-2 July 2004, Stockholm, Vol. II: 699-706, ICOMOS, Sweden.

11. Küçükkaya, A.G., 2004. Taşların Bozulma Nedenleri, Koruma Yöntemleri, İstanbul.

12. Öcal, A.D., 2001. Deterioration of Archaeological Environment in the Eastern Mediterranean, in: Günisiginda Anadolu- 
Anatolia in Daylight, Essays in Honour of Cevdet Bayburtluoglu, C. Özgünel, O. Bingöl, V. Idil, S. Doruk, K. Gorkay, M. Kadioglu (eds), Homer Kitabevi, İstanbul.

13. Öcal, A.D., Dal, M., 2013. Investigations on Stone Weathering of Ottomn Architecture: A Kirklareli Hizirbey Kulliye Case Study, In: Indian Journal of Research, Volume: 2, Issue:11, Nov 2013.

14. Orball1, A., 2008. Architectural Conservation: Principles and Practice, Blackwell Science, Oxford. 
